\title{
ORAL PROBIOTIK: PENDEKATAN BARU TERAPI HALITOSIS (Tinjauan Pustaka)
}

\author{
Indrayadi Gunardi,* Yuniardini S Wimardhani** \\ * Peserta Program Dokter Gigi Spesialis Penyakit Mulut FKG UI \\ ** Staf Pengajar Departemen Ilmu Penyakit Mulut FKG UI
}

\begin{abstract}
Halitosis is a general term denoting unpleasant breath arising from mouth, where odorous breath components could be originated from intraoral and/or extraoral. Classification includes genuine halitosis, pseudo-halitosis and halitophobia. Local and systemic factor play role in the process of halitosis. Diagnosis of halitosis can be made by analysing the degree and type of the presence of volatile compounds, as well as the identification of microbial components. Currently available treatments of halitosis includes local (mechanic and chemical) and systemic (probiotic) approaches. Probiotic is a new therapeutic approach for halitosis. Development of available probiotic-based halitosis treatments is significantly progressing and is overviewed herein.
\end{abstract}

Keywords: halitosis, therapy, oral, probiotic

\section{Pendahuluan}

Halitosis merupakan kondisi yang umum dijumpai dalam masyarakat, dan perawatan ke dokter atau dokter gigi kerap dilakukan setelah timbul masalah sosial. Faktor lokal yang berperan dalam timbulnya halitosis adalah adanya penyakit gingiva dan periodontal. Metode terapi halitosis biasanya bertujuan untuk menghilangkan faktor lokal tersebut, dapat berupa mekanis (penyikatan gigi dan lidah), kimiawi (permen karet, obat kumur) dan kontrol diet. ${ }^{1}$ Saat ini sedang dikembangkan metode terapi halitosis menggunakan bahan biologis yaitu dengan menggunakan bakteri probiotik. Makalah ini akan memaparkan hasil studi literatur tentang perkembangan terapi halitosis dengan probiotik.

\section{Telaah Pustaka}

\section{Halitosis}

\subsection{Etiologi dan patogenesis halitosis}

Halitosis didefinisikan sebagai bau tidak enak yang keluar dari rongga mulut, tanpa melihat sumber bahan odorus dalam nafas baik dari oral maupun non-oral. ${ }^{2}$ Klasifikasi halitosis dibagi menjadi genuine halitosis, pseudo halitosis dan halitofobia. ${ }^{3}$

Berdasarkan penyebabnya, halitosis dapat dikelompokkan menjadi intraoral atau faktor lokal dan ekstraoral atau faktor sistemik. Dalam rongga mulut, bau mulut biasanya disebabkan 
karena kebersihan mulut yang buruk, gingivitis, periodontitis, soket gigi yang terinfeksi, sisa darah post bedah, debri yang melekat pada bahan alat gigi, ulser mulut, serostomia dan tongue coating. ${ }^{4,5}$

Secara normal, rongga mulut merupakan tempat hidup yang baik bagi banyak spesies baik bakteri, jamur, maupun virus, namun pada pasien halitosis intraoral, lebih banyak ditemukan variasi bakteri dari kokobasilus batang gram negatif dan batang gram positif. Walaupun tidak ditemukan hubungan yang pasti antara genus bakteri dengan halitosis, namun dengan adanya peningkatan diversitas spesies dalam subyek halitosis, menunjukkan bahwa interaksi dari beberapa spesies yang justru menimbulkan halitosis. ${ }^{6}$

Kebanyakan komponen odor berasal dari dekomposisi protein diman terdapat sepuluh komponen organik volatil pada pasien halitosis oral berurutan dari yang terbesar sampai terkecil adalah methylbenzene, 2,2-dimethyldecane, 2,2,3,3-tetramethylbutane, 2-propanone, 3methyl-5-propylnonane, methylcyclohexane, 3methylhexane, 2-methyl-1-propene, etanol dan methylcyclopentane..$^{7}$ Bahan odor oral yang dihasilkan oleh mikroorganisme antara lain komponen sulfur volatil (terutama metil merkaptan $\left[\mathrm{CH}_{3} \mathrm{SH}\right]$, hidrogen sulfida $\left[\mathrm{H}_{2} \mathrm{~S}\right]$ dan dimetil sulfida $\left[\mathrm{CH}_{3} \mathrm{SCH}_{3}\right]$ ), poliamin (putresin dan kadaverin) dan asam lemak rantai pendek (asam butirat, asam valerat dan asam propionik). ${ }^{8} \quad$ Komponen sulfur volatil menempati $90 \%$ dari total udara dalam rongga mulut. Dalam penelitian yang menganalisis hubungan bakteri penghasil odor dan jenis odor, ditemukan bahwa Prevotella intermedia, Prevotella nigrescens dan Treponema denticola berkorelasi dengan kadar hidrogen sulfida; Porphyromonas gingivalis, $P$. intermedia, dan Tannerella forsythensis berkorelasi dengan kadar metil merkaptan (Tabel 1). ${ }^{9}$ Selanjutnya, metil merkaptan merupakan penyebab utama halitosis dibandingkan hidrogen sulfida dan dimetilsulfida; dimana metil merkaptan dan hidrogen sulfida berasal dari intraoral, sedangkan dimetilsulfida diduga berasal dari ekstraoral. ${ }^{10}$
Tabel 1. Jenis bakteri yang menghasilkan komponen sulfur volatil intraoral dari intraoral, seperti hidrogen sulfida dan metil merkaptan. ${ }^{9}$

\begin{tabular}{l|c}
\hline \multicolumn{1}{c|}{ Bakteri } & $\begin{array}{c}\text { Komponen sulfur } \\
\text { volatil }\end{array}$ \\
\hline P. intermedia & hidrogen sulfida \\
P. nigrescens & \\
T. denticola & \\
\hline P. gingivalis & metil merkaptan \\
P. intermedia & \\
T. forsythensis & \\
\hline
\end{tabular}

Penyebab ekstraoral dari halitosis antara lain sinusitis kronik, faringitis, laringitis, tonsilitis dan tonsiloliths. ${ }^{11}$ Selain itu, penggunaan obat-obatan seperti kloral hidrat, isorbid dinitrat, dimetil sulfoksida, dilsulfiram, bahan sitotoksik, paraldehid, dan triamteren serta penyakit sistemik seperti diabetes melitus, penyakit pada sistem respiratorius atau gastrointestinal, gagal organ hepar atau renal, dan gangguan metabolik trimetilamin juga berperan dalam timbulnya halitosis. ${ }^{10,12}$

Pada halitosis ekstraoral, 90\% substansi penyebab dalam saluran gastrointestinal adalah asam lemak (asam asetat, asam propionik dan asam butirat), 6,5\% amoniak dan sisanya adalah komponen sulfur (hidrogen sulfida, dan metil merkaptan) dan komponen nitrogen (indol, skatol, piridin, pirol, amonia, trimetilamin). ${ }^{13}$

\subsection{Diagnosis}

Secara umum, diagnosis halitosis dapat dilakukan dengan identifikasi kadar bahan volatil yang dihasilkan dan identifikasi mikroba penyebab halitosis. Penggunaan halimeter yang berfungsi mengukur kadar sulfida volatil ${ }^{14}$, tes BANA (N-benzoyl-DL-arginine-2naphthylamide) yang mengukur kadar sulfida sulkus gingiva ${ }^{15}$, kromatografi gas $^{16}$, pengukuran dengan organoleptik ${ }^{16}$, electronic nose $^{16}$, pemeriksaan kadar salivary $\beta$ galactosidase $^{14}$, metoda ninhydrine (kadar amin

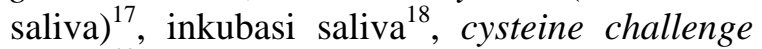
testing ${ }^{19}$ merupakan beberapa cara identifikasi kadar bahan volatil penyebab halitosis.

Cara identifikasi mikroba penyebab halitosis antara lain dilakukan dengan 
hibridisasi DNA dan real time PCR yang spesifik untuk bakteri tertentu. ${ }^{20}$ Tehnik kultur mikroba penyebab halitosis, sepertinya tidak dapat digunakan karena sekitar 50\% mikrobiota oral tersebut tidak dapat dikultur. ${ }^{20}$

Tabel 2. Metode diagnosis halitosis dikelompokkan menjadi identifikasi bahan volatil dan identifikasi mikroba. ${ }^{14-20}$

\begin{tabular}{|c|c|}
\hline $\begin{array}{l}\text { Identifikasi } \\
\text { bahan volatil }\end{array}$ & $\begin{array}{l}\text { Halimeter } \\
\text { tes BANA ( } N \text {-benzoyl-DL-arginine-2- } \\
\text { naphthylamide) } \\
\text { kromatografi gas } \\
\text { pengukuran dengan organoleptik } \\
\text { electronic nose } \\
\text { pemeriksaan kadar salivary } \beta \text { - } \\
\text { galactosidase } \\
\text { metoda ninhydrine } \\
\text { inkubasi saliva } \\
\text { cysteine challenge testing }\end{array}$ \\
\hline $\begin{array}{l}\text { Identifikasi } \\
\text { mikroba }\end{array}$ & $\begin{array}{l}\text { Hibridisasi DNA } \\
\text { Real time PCR } \\
\text { Kultur }\end{array}$ \\
\hline
\end{tabular}

\subsection{Terapi}

Untuk mengatasi halitosis intraoral, dapat dilakukan kontrol terhadap kebersihan mulut, kesehatan jaringan lunak dan keras mulut faktor-faktor pendukung timbulnya halitosis, penggunaan bakteri lain untuk menekan bakteri anaerob gram negatif, dan terapi antimikrobial. ${ }^{1,3}$ Upaya menghilangkan faktor lokal dapat dilakukan secara 1) mekanis dengan cara penyikatan lidah dan gigi, dan 2) kimiawi melalui penggunaan obat kumur, pasta gigi, permen karet; dan sistemik kontrol diet dan terapi biologis dengan menggunakan probiotik.

Pembersihan gigi dan mulut secara mekanis bertujuan untuk mengurangi jumlah mikroba patogen dari biofilm dan tongue coating, sehingga pembentukkan karies dihambat, kadar halitosis menjadi rendah dan risiko penyakit sistemik dapat berkurang. ${ }^{3}$

Secara kimiawi, penggunaan obat kumur klorheksidin diglukonat juga memberikan hasil yang baik terhadap timbulnya halitosis. ${ }^{21}$ Bahan lain yang juga dapat memperbaiki kondisi halitosis antara lain zinc chloride dan sodium chloride $^{22}$, TCF (triclosan, copolimer dan $\mathrm{NaF})^{23}$, oxygen release device ${ }^{24}$, oxohalogen oxidant (campuran chlorite anion dan chlorine dioxide $)^{25}$ serta minyak esensial ${ }^{26}$.

Kombinasi terapi mekanik dan kimiawi ternyata dapat memperbaiki kondisi halitosis oral, ditandai dengan penurunan kadar komponen sulfur volatil dan organoleptik. ${ }^{1}$ Contohnya, pada pasien dengan gigi tiruan, penyikatan gigi tiruan saja ternyata tidak dapat mengurangi halitosis, tetapi penyikatan gigi yang disertai perendaman gigi tiruan dalam larutan antiseptik, ternyata jauh lebih efektif. ${ }^{27}$ Dahulu permen karet sering digunakan untuk menghilangkan bau mulut, tetapi ternyata permen karet tidak bergula justru akan meningkatkan kadar metil merkaptan. ${ }^{21}$ Rasa mint dalam permen, tidak menurunkan konsentrasi metil merkaptan, tetapi hanya menutupi malodor oral saja.

Modifikasi faktor pendukung timbulnya halitosis, dapat dilakukan dengan mengurangi diet protein. Adanya keseimbangan diet protein dan karbohidrat akan mengurangi pembentukan bahan odor. Daging yang masih berdarah, daging ikan, susu fermentasi, dapat meningkatkan metabolisme protein sehingga bahan odor yang terbentuk akan meningkat pula. Makanan yang banyak mengandung mineral sulfat, juga dapat menimbulkan halitosis. Berdasarkan penelitian, jika makanan yang banyak mengandung bahan odor dianginkan pada udara kering maka akan mengurangi jumlah mikroorganisme anaerob yang ada didalamnya. $^{28}$

Dewasa ini, dengan banyaknya penelitian rekayasa genetik, banyak bakteri normal maupun patogen, dirancang untuk tidak lagi menimbulkan kondisi patogen bagi tubuh. Bakteri ini dapat menjadi probiotik. Penggunaan probiotik sudah lama dilakukan pada kondisi sistemik, tetapi untuk rongga mulut, hal ini masih relatif baru.

\section{Probiotik}

\subsection{Mekanisme kerja probiotik}

Probiotik pertama kali digunakan dalam bidang kedokteran, sebagai terapi atau pencegahan terhadap diare akibat antibiotik. Terapi antibiotik biasanya akan membunuh bakteri penyebab penyakit dan bakteri normal. 
Bakteri normal intestinal berfungsi dalam menjaga keseimbangan saluran pencernaan normal. Beberapa bakteri bersifat lebih resisten terhadap antimikrobial tertentu, sehingga bakteri tersebut akan mendominasi gastrointestinal dengan cepat jika kompetitor (bakteri yang dihambat oleh antimikrobial) berkurang jumlahnya. Hal ini menimbulkan gangguan keseimbangan ekologi yang memudahkan timbulnya infeksi dan imunoinflamasi. Probiotik berfungsi untuk mengembalikan keseimbangan mikroflora secara optimal sehingga dapat mencegah dan memperbaiki kondisi penyakit. ${ }^{1}$

Berdasarkan definisi WHO, probiotik adalah mikroorganisme hidup yang jika diberikan dalam jumlah tertentu dapat memberikan dampak sehat bagi host. ${ }^{29}$ Dalam saluran pencernaan, penggunaan prebiotik dan probiotik ditujukan untuk meningkatkan resistensi terhadap patogen intestinal eksogen, kontrol penyakit akibat mikrobiota patogen intestinal, mengurangi metabolisme toksigenik mikrobial dalam usus dan memodulasi sistem imun host. ${ }^{30}$ Dahulu diduga bahwa efek positif dari probiotik didapatkan melalui modifikasi genetik sehingga strain bakteri dapat menghasilkan antibodi, enzim dan sitokin. Sekarang diketahui bahwa mekanisme toleransi probiotik adalah meregulasi respon imun terhadap fragmen makanan potensial antigenik dan menghilangkan adhesi bakteri patogen dan menggantikannya dengan bakteri non-patogen (Gambar 1). ${ }^{8}$

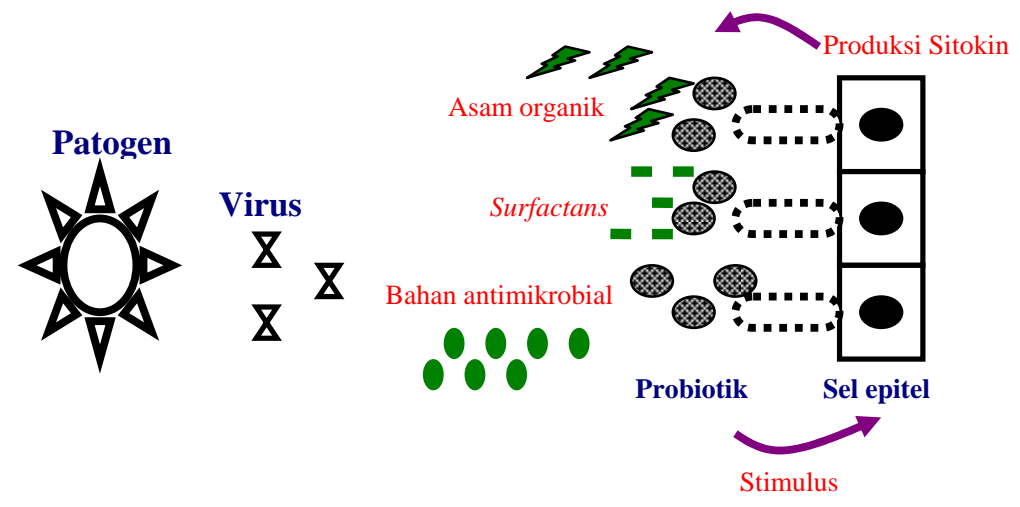

Gambar 1. Efek bakteri probiotik terhadap sel epitel tubuh, yaitu sekresi asam organik, surfactans, bahan antimikrobial (bacteriocin dan hidrogen peroksida). Probiotik juga akan berkompetisi dengan patogen melalui adhesi dan pertukaran stimulus dengan reseptor sel epitel sehingga terjadi sekresi sitokin yang akan menghambat patogen dan virus. ${ }^{31}$

Hal ini yang membedakannya dengan penggunaan antimikrobial untuk terapi halitosis. Penggunaannya dalam jangka waktu pendek, akan menghilangkan halitosis sampai bakteri penyebab halitosis kembali mendominasi lingkungan rongga mulut. Penggunaan antimikrobial spesifik tidak mungkin dilakukan, karena penyebab halitosis sendiri bersifat kompleks dan masih banyak bakteri dalam rongga mulut penyebab halitosis yang belum ditemukan hingga kini. ${ }^{8}$ Oleh karena itu, diajukan alternatif lain dengan menggunakan bakteri non-virulen berupa mikroorganisme komensal, yang dapat menghambat pertumbuhan organisme penyebab halitosis kembali.

Sejak dahulu, manusia telah mengkonsumsi bakteri asam laktik dalam bentuk makanan maupun probiotik, namun penggunaan bakteri lainnya, dikuatirkan dapat menimbulkan efek samping buruk terhadap kesehatan. Akhir-akhir ini, banyak perkembangan dalam penemuan probiotik baru, seperti bakteri dari mukosa intestinal yang digunakan pada mukosa oral. Bakteri laktobasilus dari intestinal ini pernah dicoba digunakan untuk probiotik oral, tetapi nampaknya kurang memberikan efek positif 
daripada bakteri yang diisolasi langsung dari mikrobiota oral. ${ }^{1}$ Kandidat probiotik oral ini diharapkan dapat bertahan dalam kondisi ekosistem oral. Bakteri normal mulut yang telah dicoba digunakan sebagai probiotik antara lain Lactococcus lactis ${ }^{1}$, Lactobacillus acidophilus ${ }^{32}$, Streptococcus thermophilus ${ }^{1}$, Streptococcus mutans $^{33}$, dan Streptococcus salivarius ${ }^{1}$.

Dari semua spesies, $S$. salivarius merupakan kandidat probiotik yang sangat baik, dapat menempati lingkungan biofilm dengan jumlah dominan pada lidah. Bakteri ini dapat menghasilkan sangat sedikit komponen sulfur volatil dan tidak berimplikasi terhadap karies gigi maupun penyakit infeksius lainnya. Strain bakteri ini hampir menyerupai $S$. thermophilus yang dahulu disebut $S$. salivarius ssp. Thermophilus dan sudah banyak digunakan dalam industri makanan. Jadi, S. salivarius dipilih menjadi probiotik karena karakteristik bakteri berupa bakteriosin yang dihasilkan akan menetap dalam rongga mulut, dapat ber-adhesi pada berbagai sel dalam mulut, dapat dibekukan dan disimpan, menghasilkan bakteriosin tipe lantibiotik yang poten terhadap bakteri gram positif. $^{1}$

\subsection{Penggunaan probiotik dalam bidang kedokteran gigi}

Banyak usaha telah dilakukan dalam upaya menggunakan bakteri intestinal normal (seperti laktobasilus) untuk rongga mulut, tetapi nampaknya bakteri yang diisolasi dari dalam rongga mulut lebih dapat bermanfaat daripada bakteri intestinal. ${ }^{1}$ Tidak semua probiotik dapat mengisi populasi mikrobial dalam rongga mulut, karena setiap strain bakteri memiliki afinitas terhadap jaringan tertentu. ${ }^{1}$ Selain itu, bakteri juga dapat menghasilkan bacteriocin, yang berfungsi untuk membunuh bakteri kompetitor sehingga probiotik mendapatkan nutrien yang optimal dalam lingkungan tempatnya. ${ }^{34}$ Hingga sekarang, dalam bidang kedokteran gigi, probiotik telah digunakan sebagai terapi preventif untuk karies gigi, Candidam albicans dan halitosis.

Probiotik telah banyak digunakan sebagai terapi preventif terhadap karies gigi. Strain Streptococcus thermophilus dan Lactococcus lactis dapat melemahkan pembentukkan biofilm plak gigi. ${ }^{1}$ Begitu pula dengan probiotik laktobasilus yang berasal dari usus, dapat menekan pertumbuhan $S$. mutans. ${ }^{1}$

\subsection{S. salivarius K12 sebagai bakteri probiotik untuk terapi halitosis}

Streptococcus salivarius, Rothia mucilaginosa dan spesies Eubacterium, merupakan bakteri normal yang ditemukan pada individu sehat. ${ }^{8}$ Streptococcus salivarius K12 merupakan prototipe dari strain $S$. salivarius yang mempunyai efek inhibisi tinggi terhadap bakteri lain dalam kelompok bacteriocin streptokokus (probiotik ini menghasilkan lantibiotik 2,368-Da salivaricin A2 atau SalA2 dan lantibiotik 2,740-Da salivaricin B atau SboB) sehingga dapat digunakan untuk pencegahan dan terapi halitosis. ${ }^{35}$ Lantibiotik disebut juga sebagai class $I$ bacteriocin, mengandung asam amino lanthionine yang telah dimodifikasi post-translasional dan/atau methyllanthionine; pada $S$. salivarius dihasilkan salivaricin $A$ dan $B .{ }^{36}$ Gambar 1 memperlihatkan diagram fungsi bacteriocin.

S. salivarius K12 tidak dapat menghambat semua spesies yang berperan dalam halitosis, terutama koloni berpigmen hitam (beberapa spesies Prevotella) dalam sampel saliva. ${ }^{37}$ S. salivarius ini sangat efektif dalam menekan pertumbuhan Micrococcus luteus, Streptococcus anginosis, Eubacterium saburreum dan Micromonas micros, yang pada akhirnya menurunkan kadar komponen sulfur volatil. ${ }^{37}$ Mekanisme yang diduga berperan disini adalah kompetisi melalui saturasi perlekatan bakteri (bakteriosin) ke mukosa mulut, karena secara in vitro, S. salivarius tidak dapat menghambat semua spesies yang menjadi penyebab halitosis intraoral, yaitu $P$. gingivalis dan P. intermedia. $^{37}$

Produksi salivaricin A dalam saliva, sangat bervariasi antar individu dan untuk dapat menghasilkan sejumlah salivaricin yang dapat dideteksi, diperlukan $S$. salivarius $\mathrm{K} 12$ per mililiter saliva sebanyak $8 \times 10^{5}$ sampai $6,7 \times$ $10^{7}$ CFU per ml. ${ }^{36}$ Kondisi ini juga dipengaruhi oleh laju aliran saliva yang dapat mendilusi salivaricin A. S. salivarius K12 selain dapat 
digunakan sebagai terapi halitosis, juga dapat digunakan sebagai terapi infeksi faringeal akut yang disebabkan Streptococcus pyogenes. ${ }^{36}$

\section{Pembahasan}

Penelitian klinis pada pasien halitosis yang diberikan obat kumur klorheksidin dan probiotik lozenges strain K12, memperlihatkan bahwa 8 dari 13 pasien mengalami perbaikan kadar komponen sulfur volatil dalam 2 minggu. Sebagai pilihan terapi halitosis, S. salivarius K12 tidak dapat digunakan secara tunggal, namun harus dikombinasikan dengan pembersihan mekanis dan kimiawi agar bakteri penghasil halitosis dapat disingkirkan dan selanjutnya populasi bakteri mulut akan digantikan dengan $S$. salivarius K12. ${ }^{1}$ Jadi penggunaan probiotik dilakukan sesudah pembersihan mekanis dan kimiawi dalam rongga mulut.

Saat kini, S. salivarius K12 sudah banyak ditemukan dalam pasaran dan dikemas dalam bentuk bubuk $^{38}$, lozenges ${ }^{39,40}$, dan permen
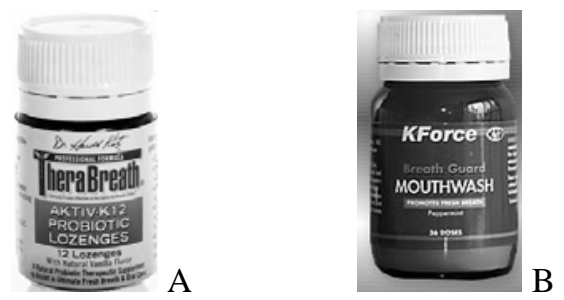

karet $^{41}$. Kemasan bubuk dapat digunakan untuk terapi halitosis dengan cara ditambahkan air dan dikumur selama 30 detik dan gargle selama 5 detik kemudian dibuang. ${ }^{38}$ Penggunaannya sangat dianjurkan setelah atau selama penggunaan antibiotik, profilaksis mencegah penyakit sore throat, dan aman digunakan bagi wanita hamil maupun menyusui. ${ }^{40}$ Hal ini dilakukan karena bahan medikasi baik antibiotik maupun antiseptik, dapat menyebabkan kematian bakteri patogen maupun komensal serta meningkatkan populasi spesies kandida dalam mulut. Tetapi jika penggunaan antibiotik dihentikan, maka kondisi flora mulut akan kembali seperti semula. Probiotik dapat diberikan selama pemberian antibiotik, supaya populasi bakteri dalam mulut, lebih didominasi oleh bakteri normal komensalis. Efektivitas $S$. salivarius K12 telah diuji secara klinis mampu memperbaiki kondisi halitosis, begitu pula dengan keamanannya, tanpa menimbulkan efek samping apapun karena bakteri tersebut mempunyai potensi patogenik sangat rendah pada individu sehat. ${ }^{42}$
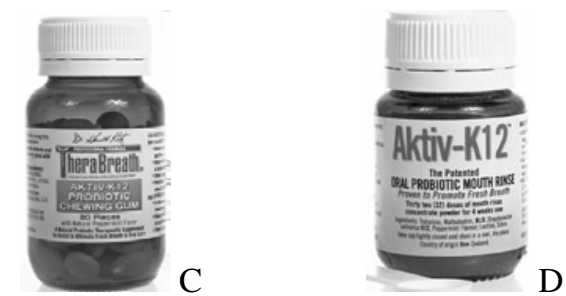

Gambar 2. Jenis kemasan probiotik Streptococcus salivarius K12 yang tersedia di pasaran; A sediaan lozenges; B sediaan obat kumur; C sediaan permen karet; dan D sediaan bubuk. ${ }^{38-41}$

\section{Kesimpulan}

Probiotik bersifat aman untuk dikonsumsi manusia dan peran terapeutiknya dapat semakin baik dengan dimengertinya kondisi flora mikrobial dan hubungannya dengan fisiologi manusia serta etio-patogenesis terhadap penyakit. Bahan makanan yang mengandung probiotik tentunya semakin lama semakin dapat diterima di masyarakat, tanpa melihat kondisi ekonomi maupun sosial. Organisme kandidat probiotik baru dapat diciptaan melalui rekayasa genetik, merubah bakteri patogen menjadi non- patogen, sehingga didapatkan fungsi fisiologik yang aplikatif untuk mempertahankan kesehatan atau mencegah dan mengobati penyakit. Saat ini penggunaan probiotik $S$. salivarius K12 baru ditujukan sebagai terapi halitosis intraoral, sedangkan untuk terapi halitosis ekstraoral masih belum dikembangkan. Secara intraoral, penggunaan probiotik sebaiknya dikombinasikan dengan pembersihan mekanis dan kimiawi, sedangkan secara sistemik, penggunaan probiotik dapat digunakan setelah terapi antibiotik. 


\section{Daftar Pustaka}

1. Burton JP, Chilcott CN, Tagg JR. The rationale and potential for the reduction of oral malodour using Streptococcus salivarius probiotics. Oral Dis 2005;11(Suppl. 1):29-31.

2. Tonzetich J. Production and origin of oral malodor: a review of mechanism and methods of analysis. J Periodontol 1977;48:13-20.

3. Yaegaki K, Coil JM. Examination, classification and treatment of halitosis; clinical perspectives. J Can Dent Assoc 2000;66(5):257-61.

4. Figueiredo LC, Rosetti EP, Marcantonio Jr E, Marcantonio RAC, Salvador SL. The relationship of oral malodor in patients with or without periodontal disease. $J$ Periodontol 2002;73(11):1338-42.

5. Verran J. Malodour in denture wearers: an illdefined problem. Oral Dis 2005;11(Suppl. 1):24-8.

6. Donaldson AC, McKenzie D, Flanagan AJ, Riggio MP. Microbiological culture analysis of the tongue microflora in subjets with and without halitosis. Oral Dis 2005;11(Suppl. 1):120.

7. Phillips M, Nachnani S, Cataneo RN, Greenberg J. Volatile markers of oral malodor in the breath. Oral Dis 2005;11(Suppl. 1):101.

8. Kazor CE, Mitchell PM, Lee AM, Stokes LN, Loesche WJ, Dewhirst FE, Paster BJ. Diversity of bacterial populations on the tongue dorsa of patients with halitosis and healty patients. J Clin Microbiol 2003;41(2):558-63.

9. Yamamoto Y, Tanaka M, Ehara M, Nonaka A, Anguri H, Kuboniwa M, Shizukuishi S. Relationship of oral malodor with tongue microbiota analyzed with real-time PCR. Oral Dis 2005;11(Suppl. 1):115.

10. Murata T, Fujiyama Y, Yamaga T, Miyazaki H. Breath malodor in an asthmatic patients caused by side-effects of medication: a case report and review of the literature. J Oral Dis 2003;9:273-6.

11. van Den Broek AMWT, Feenstra L, De Baat C. Complaints of halitosis related to the oral cavity. A preliminary report of 700 consecutive patients. Oral Dis 2005;11(Suppl. 1):107-8.

12. Mitchell SC. Trimethylaminuria (fish-odour syndrome) and oral malodour. $J$ Oral Dis 2005;11(Suppl 1):10-3.

13. Sato $H$, Hirose $T$, Kimura $T$, Moriyama $Y$, Nakashima Y. Analysis of malodorous volatile substances of human waste: feces and urine. $J$ Health Sci 2001;47(5):483-90.
14. Knaan T, Cohen D, Rosenberg M. Predicting bad breath in the non-complaining population. Oral Dis 2005;11(Suppl. 1):105-6.

15. Morita M, Lay Wang H. Relationship of sulcular sulfide level and oral malodor in subjects with periodontal disease. $J$ Periodontol 2001;72(1):79-84.

16. Nonaka A, Tanaka M, Anguri H, Nagata H, Kita J, Shizukuishi S. Clinical assessment of oral malodor intensity expressed as absolute value using electric nose. Oral Dis 2005;11(Suppl. 1):114.

17. Iwanicka-Grzegorek E, Lipkowska E, Kepa J, Michalik J, Wierzbicka M. Comparison of ninhydrine methods of detecting amine compounds with other methods of detection in halitosis. Oral Dis 2005;11(Suppl. 1):114.

18. Quirynen M, Zhao H, Soers C, Pauwels M, Van Steenberghe D. Saliva incubation as replacement for intra-oral malodour evaluation. Oral Dis 2005;11(Suppl. 1):116.

19. Kleinberg I, Codipilly DM. Cysteine challenge testing: a powerful tool for examining oral malodour processes and treatments in vivo. Int Dent J 2002;52(Suppl 3):221-8.

20. Spratt D. Use of molecular identification techniques to study oral microbes and microcosms. Oral Dis 2005;11(Suppl. 1):102-3.

21. Yaegaki K, Coli JM, Kamemizu T, Miyazaki H. Tongue brushing and mouth rinsing as basic treatment measure for halitosis. Int Dent $J$ 2002;52(Suppl 3):192-6.

22. Codipilly DP, Kaufman HW, Kleinberg I. Use of a novel group of oral malodor measurements to evaluate an anti-oral malodor mouthrinse (TriOralTM) in humans. $J$ Clin Dent 2004;15(4):98-104.

23. Niles H, Hunter C, Vazquez J, Williams M, Cummins D. Clinical comparison of a triclosan/copolymer/NaF dentrifice and a commercially available breath-freshening dentrifice in reducing breath volatile sulfur compounds overnight: a multiple-use study. Oral Dis 2005;11(Suppl. 1):111.

24. Choi YG. Effect of intraoral oxygen release device on breath odor. Oral Dis 2005;11(Suppl. 1):110.

25. Silwood CJ, Grootveld MC, Lynch E. A multifactorial investigation of the ability of oral health care products (OHCPs) to alleviate oral malodour. J Clin Periodontol 2001;28(7):634-41.

26. Takarada K. The effects of essential oils on periodontopathic bacteria and oral halitosis. Oral Dis 2005;11(Suppl. 1):115. 
27. Sazvar SMR, Dashti MH, Afshan BK. Effectiveness of a mechanic-chemical method in reducing malodor of dentures. Oral Dis 2005;11(Suppl. 1):119.

28. Powers W. The science of smell part 4: Principles of odor control. 2004. Available at: www.extension.iastate.edu/Publications/PM196 3D.pdf. Accessed 23 Juli 2007.

29. Reid G. The importance of guidelines in the development and application of probiotics. Curr Pharmaceutic Design 2005;11:11-6.

30. Crittenden R, Bird AR, Gopal P. Henriksson A, Lee YK, Playne MJ. Probiotic research in Australia, New Zealand and the Asia-Pacific region. Curr Pharm Design 2005;11(1):37-53.

31. O’Sullivan GC, Kelly P, O’Halloran S, Collins C, Collins JK, Dunne C, Shanahan F. Probiotics: an emerging therapy. Curr Pharm Design 2005;11(1):3-10.

32. Elahi S, Pang G, Ashman R, Clancy R. Enhanced clearance of Candida albicans from the oral cavities of mice following oral administration of Lactobacillus acidophilus. Clin Exp Immunol 2005;141:29-36.

33. Qi F, Chen P, Caufield PW. The group I strain Streptococcus mutans, UA140, produces both the Lantibiotic Mutacin I and a Nonlantibiotic Bacteriocin, Mutacin IV. Appl Environ Microbiol 2001;67(1):15-21.

34. Wang BY, Kuramitsu HK. Interactions between oral bacteria: inhibition of Streptococcus mutans bacteriocin production by Streptococcus gordonii. Appl Environ Microbiol 2005;71(1):354-62.
35. Hyink O, Wescombe PA, Upton M, Ragland N, Burton JP, Tagg JR. Salivaricin A2 and the novel Lantibiotic Salivaricin B are encoded at adjacent loci on a 190-Kilobase transmissible megaplasmid in the oral probiotic strain Streptococcus salivarius K12. Appl Environ Microbiol 2007;73(4):1107-13.

36. Wescombe PA, Upton M, Dierksen KP, Ragland NL, Sivabalan S, Wirawan RE, Inglis MA, Moore CJ, Walker GV, Chilcott CN, Jenkinson HF, Tagg JR. Production of the Lantibiotic Salivaricin A and its variants by oral Streptococci and use of a specific induction assay to detect their presence in human saliva. Appl Environ Microbiol 2006;72(2):1459-66.

37. Burton JP, Chilcott CN, Moore CJ, Tagg JR. Effect of probiotic Streptococcus salivarius K12 on oral malodour parameters. Oral Dis 2005;11(Suppl. 1):103.

38. Katz H. Aktiv K-12 Probiotics. Available at: http://www.therabreath.com/probiotics_directio ns.asp. Last update 2008. Accessed July 30, 2008.

39. Australian Breath Clinic. Kforce Breath Recovery Program. Available at: http://www.breezecare.com/usa/index.html. Last Update Sept 5, 2008. Accessed July 30, 2008

40. Blis K-12 Throat Guard. Available at: http://www.onlinepharmacy.co.nz/index.cfm/lay out/Brand/BrandID/251/CatID/9. Accessed July 30, 2008

41. Katz H. Probiotic chewing gum. Available at: http://www.therabreath.com/productdetail.asp?c at=22\&pid=283. Accessed July 30, 2008.

42. Burton JP, Wescombe PA, Moore CJ, Chilcott CN, Tagg JR. Safety assessment of the oral cavity probiotic Streptococcus salivarius K12. Appl Environ Microbiol 2006;72(4):3050-3. 